\title{
Formulation and evaluation of orally dispersible tablets of Chlorpheniramine maleate by fusion method
}

\author{
Vivek DAVE, Renu Bala YADAV, Richa AHUJA, Atul Kumar SAHU
}

\begin{abstract}
Many conventional dosage form comes in market to achieve their therapeutic value as it administered through the given route. But sometimes People feel trouble in swallowing of conventional dosage forms like tablet and capsule without taking water or due to lack availability of water during long journey. In these cases, rapidly disintegrating tablets in oral cavity are paid attention nowadays. These are known as orally dispersible tablets which disintegrate in mouth as put on tongue resulting in release of drug which dissolve and disperse in saliva. Drug rapidly converts into solution from solid form resulting in rapid absorption and onset of action. After formulations development, evaluation of these tablets were done such as weight variation, hardness, friability, disintegration, drugpolymer interaction, FTIR studies, SEM studies, drug content, water absorption ratio, wetting time and in-vitro drug release
\end{abstract}

and short term stability studies. These tablets (all formulations that is F1-F10) showed weight variation in range of $253 \pm 0.05$ to $291 \pm 0.61 \mathrm{mg}$, hardness of $2.1 \pm 0.1$ to $3.5 \pm 0.07 \mathrm{Kg} / \mathrm{cm}^{2}$, friability of $0.44 \pm 0.01$ to $0.69 \pm 0.01 \%$, disintegration time of $20 \pm$ 0.08 to $34 \pm 1.1$ seconds, drug content of 92.0 to $99.18 \%$, water absorption ratio of $26 \pm 1.12$ to $49 \pm 3.01 \%$, wetting time of $53 \pm$ 1.89 to $104 \pm 4.89 \mathrm{sec}$ and in-vitro drug release showed 85.66 to $99.88 \%$ within 5 minutes. FTIR studies showed that there is no interaction between drug and polymer. Stability studies showed that there is no change in drug release upon storage on different temperature and humidity. Results revealed that orally dispersible tablets of chlorpheniramine maleate prepared by fusion method result in rapid dissolution.

Keywords: Chlorpheniramine maleate; Fusion method; FTIR; SEM; Full factorial design.
Vivek Dave, Renu Bala Yadav, Richa Ahuja

Department of Pharmacy, Banasthali University, Banasthali, Rajasthan, India

Atul Kumar Sahu

Shambhunath Institute of Pharmacy, Jhalwa, Allahabad, Uttar Pradesh, India

Corresponding Author:

Dr. Vivek Dave

Ph-+91-9694891454

E-mail: vivekdave1984@gmail.com

Submitted / Gönderilme: 31.08 .2016 Accepted / Kabul: 29.09.2016
Revised / Düzeltme: 24.09 .2016

\section{INTRODUCTION}

Chlorpheniramine maleate (CPM) is a first generation alkyl amine widely used as antihistamine drug patients to inhibit various histaminic actions in the body principally through a reversible competitive antagonism of histamine at the receptor sites [1]. Apart from the most common side effects possess by all the antihistamines, CPM has a major problem related to its oral bioavailability [2]. However, it is well absorbed from the gastrointestinal tract, its oral bioavailability is only $25-40 \%$ of the orally administered dose which is due to its high first pass metabolism [4]. Investigations have shown that desmethylchlorpheniramine (DMCP) and didesmethylchlorpheniramine (DDMCP) are the major by-products of chlorpheniramine (CP) metabolism in the liver which decreases its bioavailability [3].

Unit dosage forms such as tablets and capsules are widely and 
successfully utilized due to their simplicity but dysphagia and difficulty in swallowing are their major drawbacks among pediatric, geriatric, bed ridden patients or even those who are travelling and have little access to water [4-6]. Research and development cells of many Government and pharmaceutical companies are in constant quest of designing and improving a satisfactory formulation [6] which could overcome the problems like; poor solubility/or poor bioavailability of active pharmaceutical compounds; overcoming unpleasant taste of API's and excipients; reducing dose frequency; difficulty in swallowing; fluctuations in plasma drug concentration profile etc. to overall improve patient compliance [5].

The ability of fast tablet disintegration and dissolution to guarantee rapid availability of the drug(s) for oral absorption has been widely studied, understood and commercially manipulated [4]. Orally dispersible tablets (ODT's) have been found to be the dosage form of choice for patients suffering from nausea, vomiting or motion sickness.

The problem of low mechanical hardness associated with the development of ODTs is tackled by use of specialized primary packaging such as double-foil blister pack with a peelable aluminum lidding [1-2]. Disintegrants are one of the prominent excipients which play a crucial role in the formulation of ODT's because mechanical and disintegrating property predominantly depends on it. An efficient disintegrant may provide rapid disintegration due to the combined effect of swelling and water absorption by the formulation [3]. A very few approved disintegrants are for the formulators for pharmaceutical industries. First generation disintegrants are starches (e.g., corn starch, potato starch) and cellulose based disintegrants (e.g., microcrystalline cellulose, low substituted hydroxypropyl cellulose). The need for shorter disintegration times or more efficient disintegrants led to the development of superdisintegrants such as modified cellulose like croscarmellose sodium (CCS), crosslinked polyvinylpolypyrrolidone or crospovidone (CPD) and modified starches like sodium starch glycolate (SSG) [3].

Microcrystalline cellulose (MCC), a widely used cellulose based excipient imparts improved flow, compaction properties and exceptionally strong binding property. Its good disintegration property is attributed to swelling or capillary action and high dilution potential [9-10] studied the feasibility of MCC within ODT's as a binder due to its high compactable and pleasant taste upon tablet disintegration [9].

Croscarmellose (CCS) is a cross-linked polymer of carboxymethyl cellulose sodium. The cross-linked structure renders the polymer insoluble. The sodium carboxymethyl groups of CCS, however, enable the polymer to wick relatively large amounts of water into its matrix, causing the polymer to swell rapidly. When CCS is used in tablets, this swelling force facilitates the tablet disintegration.

Crospovidone (CPD), a synthetic disintegrant is widely used in ODT's to enhance the fast disintegration of ODT's which works on the mechanism of capillary action and swelling ability [9] due to presence aggregates of sponge-like porous structure as revealed by microscopic imaging [4]. A wide variety of cationic, anionic and non-ionic drugs can be delivered in formulations containing CPD due to its neutral characteristics [1]. CPD when used in high concentrations has dual functionality of as a binder disintegrant system due to its ability to reduce friability of the tablet considerably together with reduction in disintegration time [2].

There are various techniques for formulating orally dispersible tablets such as lyophilization, direct compression, tablet molding, sublimation, and fusion etc. In the present study, orally dispersible tablets of CPM were prepared by fusion method and superdisintegrants such as CCS, CPD and MCC have been utilized for faster disintegration. The aim of the study is to achieve objectives like enhanced patient compliance, increased bioavailability, rapid onset of action, convenience in administration, good mouth feels etc.

\section{MATERIALS AND METHODS}

\subsection{Materials}

CPM was obtained from MP Biomedicals, Mumbai, India, CCS and CPD were gifted from Dr. Reddy's laboratory, Hyderabad, India, PEG 6000 and SSG were obtained from HiMedia Pvt. Ltd., Mumbai, India, mannitol was obtained from Central Drug House Pvt. Ltd., Mumbai, India, and microcrystalline cellulose was obtained from Merck, India. All other reagents and chemicals used were of analytical grade.

\subsection{Formulation method of ODT's by fusion method}

In this study, ODT's containing CPM were prepared by fusion method according to the formulae given in Table 1. To prepare different batches, all ingredients according to the formula were accurately weighed and passed through 60 and 100 mesh sieve and mixed geometrically. Accurately weighed quantities $(300 \mathrm{mg}$ ) of this physical mixture were filled in blisters, properly wrapped with aluminum foil and kept in hot air oven for about 45 minutes at a temperature of $55^{\circ} \mathrm{C}$. Finally, the blisters were withdrawn from oven, cooled to room temperature and ODT's separated and stored in desiccator [11]. 
Table 1. Composition of ODT's by fusion method

\begin{tabular}{|c|c|c|c|c|c|c|c|c|c|c|}
\hline \multirow{2}{*}{ Ingredients (mg) } & \multicolumn{10}{|c|}{ Batch } \\
\hline & F1 & F2 & F3 & F4 & F5 & F6 & F7 & F8 & F9 & F10 \\
\hline Chlorpheniramine maleate & 50 & 50 & 50 & 50 & 50 & 50 & 50 & 50 & 50 & 50 \\
\hline Sodium starch glycolate & 10 & 20 & 30 & 10 & 10 & 10 & 10 & 10 & 10 & 10 \\
\hline Microcrystalline cellulose & 40 & 40 & 40 & 60 & 40 & 40 & 60 & 40 & 40 & 40 \\
\hline Mannitol & 100 & 110 & 80 & 60 & 70 & 60 & 30 & 70 & 80 & 80 \\
\hline Croscarmellose sodium & - & _ & 10 & 20 & 30 & 30 & 40 & 30 & 20 & 10 \\
\hline Crospovidone & - & - & 10 & 20 & 20 & 30 & 30 & 20 & 20 & 30 \\
\hline PEG 6000 & 100 & 80 & 80 & 80 & 80 & 80 & 80 & 80 & 80 & 80 \\
\hline Total & 300 & 300 & 300 & 300 & 300 & 300 & 300 & 300 & 300 & 300 \\
\hline
\end{tabular}

\subsection{Measurement of tablet tensile strength and friability}

The ability to withstand mechanical shock of handling in manufacturing, packaging and shipping is measured in terms of tensile strength or crushing load and friability. The crushing load for ODT's of various batches were determined by compressing the tablets in diametric direction using a Pfizer tablet hardness tester (Cadmach, India) [12]. The friability of tablets was determined using Roche Friabilator USP test apparatus (Electrolab, Mumbai). Randomly six ODT's were chosen from each batch and their initial weight was determined Table 2. The ODT's were placed in Friabilator and rotated at $25 \mathrm{rpm}$ for 4 minutes. The tablets were removed, dusted and their final weight was determined [13]. The formula for calculating friability is given in equation 1 as:

$F=\frac{w_{i}-w_{f}}{w_{f}} \times 100$

eq. 1

Where, $W_{i}$ is initial weight and $W_{f}$ is the final weight of the tablets.

\subsection{Measurement of disintegration time}

The in-vitro disintegration time of formulated ODT's was determined using digital disintegration apparatus (Electrolab, Mumbai, India) using $900 \mathrm{ml}$ of $\mathrm{pH} 6.8$ phosphate buffer at $37 \pm 0.5^{\circ} \mathrm{C}$. Six tablets from each batch were randomly chosen and the average time for complete disintegration of these tablets was determined (Table 2). [9-10]. All ODT's under test took 20-34 sec to disintegrate completely. Low disintegration time was achieved as a result of using two superdisintegrants CCS and CPD [14-16].

\subsection{Wetting time and Water absorption ratio}

To determine the wetting time of ODT's, a piece of tissue paper was taken and it was folded twice and placed in culture dish $(\mathrm{d}=6.5 \mathrm{~cm})$ containing about $6 \mathrm{ml}$ of purified water. An ODT having small amount of amaranth powder on upper surface was placed on tissue paper. The time elapsed in developing red color on upper surface of the ODT was determined and noted. To determine the water absorption ratio, the wetted tablets were transferred to a tissue paper and wiped off any excess water and weighed immediately [17]. Results are presented in Table 3. The water absorption ratio was calculated by following formula given in equation 2 as:

$R=\frac{w_{a}-w_{b}}{w_{b}} \times 100$

eq. 2

Where, $W_{b}$ is the weight of tablet before study and $W_{a}$ is the weight of tablet after study [19].

\subsection{Weight variation and tablet thickness}

Twenty tablets were randomly taken from each batch and their average weight was determined. Then individual tablet was taken and its weight was calculated. That individual weight was compared with average weight. The weights were measured using weighing balance [18]. Twenty tablets were randomly selected from formulations and thickness was measured individually by screw gauge. The results were expressed in millimeters (Table 2) [19-21]. 


\subsection{Drug content of solid dispersion}

Three tablets were randomly chosen from each batch, crushed and the blend equivalent to $5.0 \mathrm{mg}$ of CPM was accurately weighed and transferred to $100 \mathrm{ml}$ volumetric flask. Then $20 \mathrm{ml}$ of Phosphate buffer ( $\mathrm{pH}$ 6.8) was added under continuous stirring and volume was made up to 100 $\mathrm{ml}$ with the same. The solutions were filtered and analyzed spectrophotometrically at $261 \mathrm{~nm}$ [19]. Measurements were performed in triplicate.

Table 2. Evaluation of ODT's by fusion method

\begin{tabular}{lllllllllll}
\hline \multicolumn{1}{c}{ Test } & F1 & F2 & F3 & F4 & F5 & F6 & F7 & F8 & F9 & F10 \\
\hline $\begin{array}{l}\text { Wt. variation } \\
(\mathbf{m g})\end{array}$ & $291 \pm 0.16$ & $290 \pm 0.34$ & $288 \pm 0.40$ & $285 \pm 0.14$ & $282 \pm 0.09$ & $274 \pm 0.01$ & $270 \pm 0.07$ & $268 \pm 0.05$ & $261 \pm 0.03$ & $293 \pm 0.05$ \\
$\begin{array}{l}\text { Hardness } \\
(\text { Kg/cm })\end{array}$ & $3.5 \pm 0.07$ & $3.4 \pm 0.05$ & $3.3 \pm 0.01$ & $2.8 \pm 0.02$ & $3.2 \pm 0.09$ & $3.1 \pm 0.12$ & $3.0 \pm 0.31$ & $2.5 \pm 0.35$ & $2.3 \pm 0.18$ & $2.1 \pm 0.23$ \\
& & & & & & & & & \\
Friability (\%) & $0.69 \pm 0.01$ & $0.68 \pm 0.12$ & $0.65 \pm 0.30$ & $0.62 \pm 0.30$ & $0.60 \pm 0.12$ & $0.56 \pm 0.31$ & $0.52 \pm 0.08$ & $0.48 \pm 0.05$ & $0.47 \pm 0.03$ & $0.44 \pm 0.01$ \\
$\begin{array}{l}\text { Drug content } \\
(\%)\end{array}$ & 92 & 94.5 & 95.2 & 96.6 & 97.1 & 98.02 & 98.05 & 98.99 & 99.05 & 99.18 \\
$\begin{array}{l}\text { Thickness } \\
(\mathbf{m m})\end{array}$ & $9.03 \pm 0.12$ & $9.85 \pm 0.11$ & $9.84 \pm 014$ & $9.15 \pm 0.74$ & $9.90 \pm 0.22$ & $10.2 \pm 0.24$ & $10.32 \pm 0.24$ & $10.43 \pm 0.11$ & $10.5 \pm 0.12$ & $10.89 \pm 014$ \\
\hline
\end{tabular}

${ }^{\star}$ All data expressed as mean \pm S.D.; $n=3 ; P \leq 0.05$.

\subsection{Fourier Transform Infrared (FTIR) spectroscopy}

The FTIR spectroscopy of pure drug, CPM, the solid admixture of drug and various excipients in 1:1 ratio used in the formulations as well as the ODT's were characterized by $\mathrm{KBr}$ pellet method using Perkin Elmer FTIR Series model-1615 spectrophotometer to know the compatibility and interactions. The FTIR spectra are shown in Fig 1. The FTIR study did not show any possible interaction between CPM and superdisintegrants used in the orally dispersible tablets.

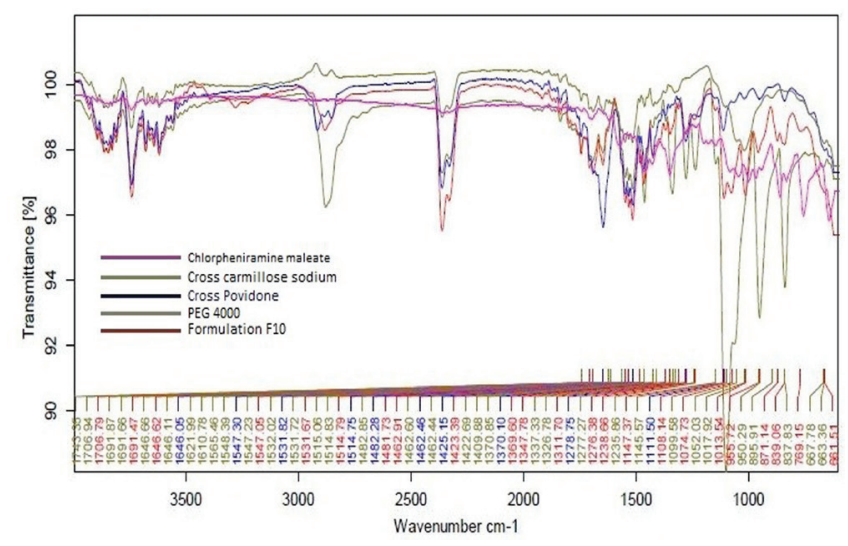

Fig 1. FT-IR of CPM and other excipients

\subsection{Scanning electron microscopy (SEM)}

The scanning electron microscopy was used to determine the morphological appearance of the formulated ODT's. The coating of ODT's was done using gold for 10 minutes with the use of fine coat ion-sputter and examined under FE-SEM (JSM 6701; JEOL, Japan). Signals of electron-sample interactions reveal information about sample including crystalline structure, chemical composition, external morphology etc. A variety of signals at the surface of solid specimens were recorded Fig $2 \mathrm{a}$ and $2 \mathrm{~b}$. The data was collected from ODT's and 2-dimensional images were generated that displayed spatial variations in these properties.

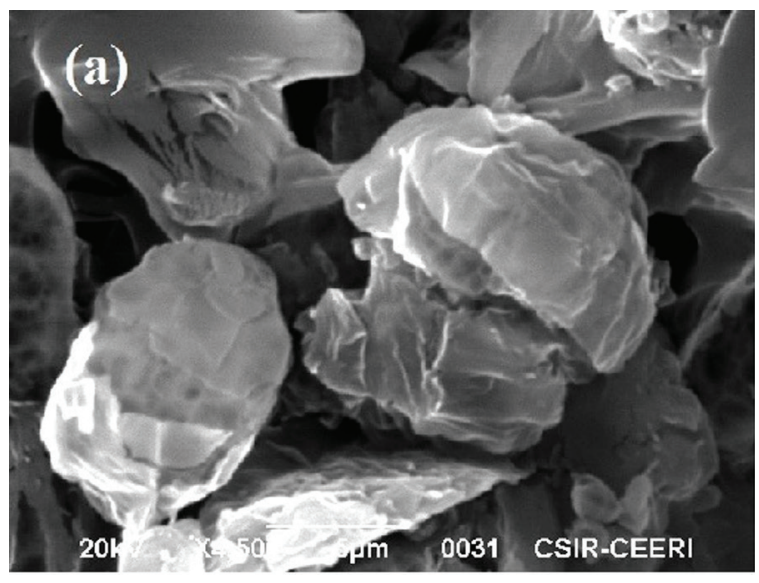




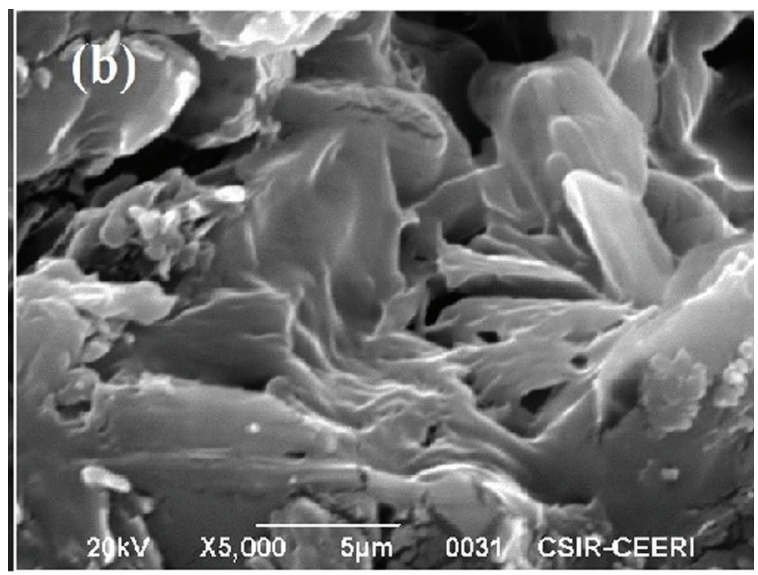

Fig 2. SEM micrograph of formulated ODT's (a) at x4500 (b) at $\mathrm{x} 5000$

\subsection{Differential scanning calorimetry (DSC)}

DSC (NETZSCH DSC 204- F1 phoenix, U.S.) thermograms of pure drug CPM, excipients used in formulations and ODT's is presented in Fig 3. DSC provides information regarding the physical properties like degree of drug crystallinity and amorphous nature of the samples. Approximately 2-4 mg of sample was taken in an aluminum pan which was heated at a scanning rate of $20^{\circ} \mathrm{C} / \mathrm{min}$ for a temperature of -50 to $220^{\circ} \mathrm{C}$. The peak area of melting endotherm was used for calculating heat of fusion. The Proteus software provided with the instrument was used to calculate the thermal peaks [22].

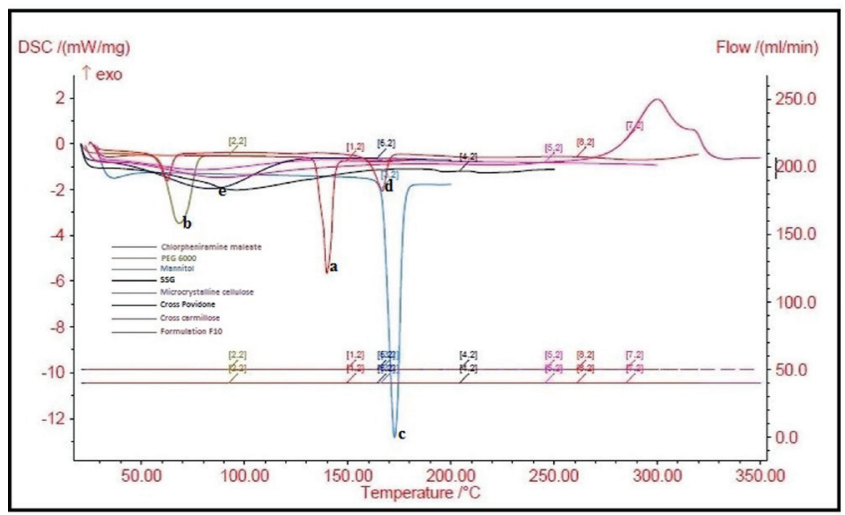

Fig 3. Combined DSC thermogram of CPM, excipients and formulated ODT

\subsection{Thermogravimetric analysis (TGA)}

TGA is a technique which helps in monitoring function of temperature or time as sample is subjected to controlled temperature program in a controlled atmosphere. It is a technique in which upon heating a material, its weight increases or decreases. TGA of CPM is shown in Fig. 4 [2324].

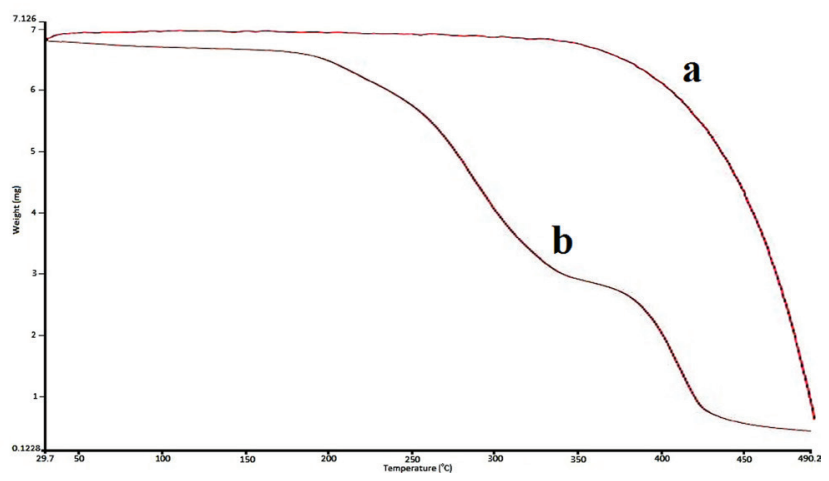

Fig 4. TGA of a) pure drug CPM, b) formulated ODT's

\subsection{In-vitro dissolution studies}

The in-vitro dissolution studies of the formulated ODT's were studied in USP dissolution apparatus type II (Tab Machines, Mumbai, India) with a paddle stirrer at $50 \mathrm{rpm}$ filled with $900 \mathrm{ml} \mathrm{pH} 6.8$ phosphate buffer at $37 \pm 0.5^{\circ} \mathrm{C}$. ODT's were placed in basket and program was set for a duration of five minutes. Aliquots of dissolution media $(2 \mathrm{ml})$ were withdrawn initially and at every 1 minute and replaced with fresh dissolution media. The samples were filtered through a $0.45 \mu$ filter membrane (Millipore, County Cork, Ireland) and absorbance was measured spectrophotometrically at $\lambda_{\max }$ $261 \mathrm{~nm}$. The dissolution test was carried out in triplicate and are presented in Fig 5 [23-25].

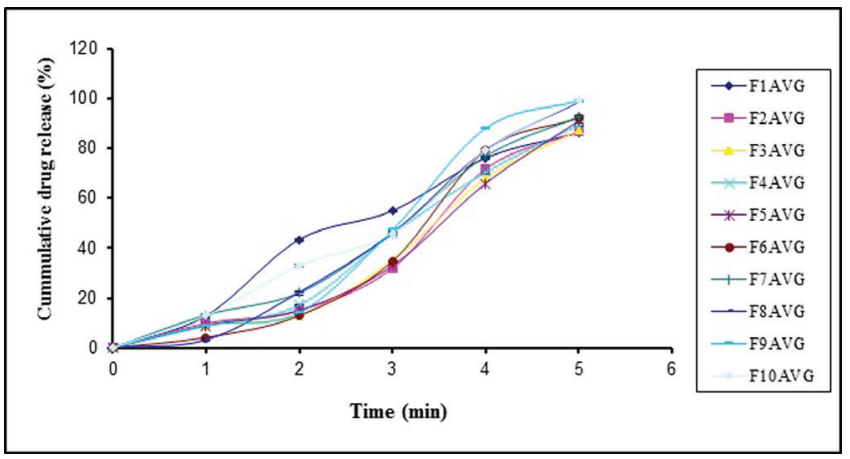

Fig 5. Dissolution graph of formulated ODT's

\subsection{Response surface methodology}

Response surface methodology (RSM) have proved to be useful statistical and mathematical techniques in modeling 
and process optimization of experimental variables which influences relevant responses and the objective of this research is to optimize these responses [25]. RSM explores the relationships between several independent variables (factors) and one or more dependent variables (responses) [26]. This design is very flexible and suitable for modeling possible curvature in the response functions and constructing second order polynomial models moreover a third level for a continuous factor facilitates investigation of quadratic relationship between the response and each of the factors (NIST/SEMATECH 2015).

Ten ODT formulations were prepared and the effect of independent variables on responses (dependent factors) were evaluated using RSM and are presented in Fig 6 [27-28]. Two independent variables were selected: the content of CPD (CP, $\left.X_{1}\right)$ and CCS $\left(C M, X_{2}\right)$ and each variable was tested at different concentrations, the quantities of which are expressed in their respective units [28-29]. The responses evaluated were: drug dissolution $\left(\% D R, Y_{1}\right)$, disintegration time $\left(D T, Y_{2}\right)$, and water absorption ratio $\left(W A R, Y_{3}\right)$ and wetting time $\left(W T, Y_{4}\right)$. Experiments were performed according to a randomized procedure and the scheme showing the values of process variables corresponding to the observed responses is reported in Table 3. Statistica V.10_ software (StatSoft, Inc. USA) was used for generation and evaluation of response surfaces.
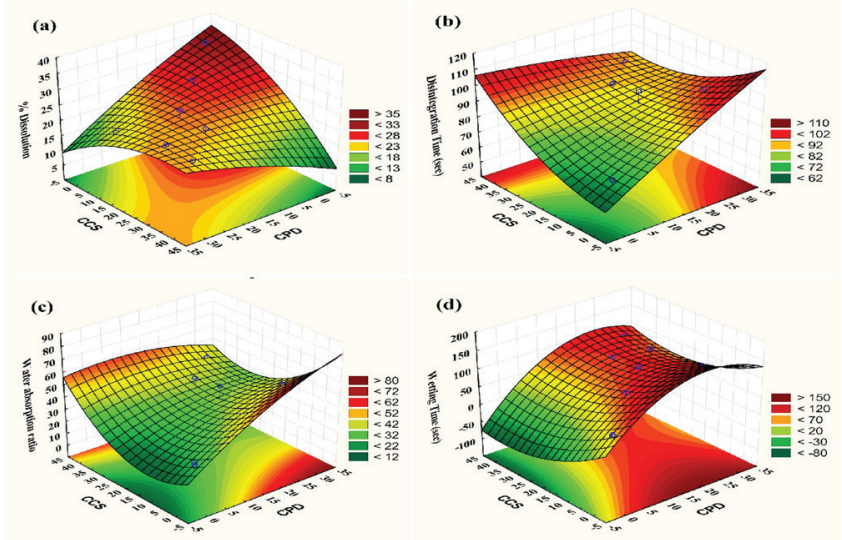

Fig 6. Response surface plots showing effect of concentration of CCS and CPD on measured responses (a) Drug dissolution (\%), (b) Disintegration time (Sec.), (c) Water absorption ratio, (d) Wetting time (Sec.).

Table 3. Process variables and their corresponding measured responses

\begin{tabular}{|c|c|c|c|c|c|c|}
\hline Batch & $\begin{array}{c}\text { Croscarmellose } \\
(\mathrm{mg})\end{array}$ & $\begin{array}{c}\text { Crospovidone } \\
\text { (mg) }\end{array}$ & $\begin{array}{c}\text { Drug } \\
\text { dissolution } \\
(\%)\end{array}$ & $\begin{array}{l}\text { Disintegration } \\
\text { time (seconds) }\end{array}$ & $\begin{array}{l}\text { Water absorp- } \\
\text { tion } \\
\text { ratio }\end{array}$ & $\begin{array}{c}\text { Wetting time } \\
\text { (sec) }\end{array}$ \\
\hline F1 & - & - & $64.67 \pm 1.60$ & $34 \pm 1.1$ & $26 \pm 1.12$ & $53 \pm 1.89$ \\
\hline $\mathrm{F} 2$ & - & - & $72.09 \pm 0.67$ & $31 \pm 1.35$ & $28 \pm 1.34$ & $56 \pm 1.0$ \\
\hline F3 & 10 & 10 & $78.78 \pm 1.49$ & $29 \pm 1.08$ & $29 \pm 1.40$ & $100 \pm 1.45$ \\
\hline F4 & 20 & 20 & $81.56 \pm 1.07$ & $27 \pm 1.42$ & $30 \pm 1.20$ & $73 \pm 1.08$ \\
\hline F5 & 30 & 20 & $86.23 \pm 0.89$ & $25 \pm 1.12$ & $32 \pm 1.09$ & $78 \pm 2.01$ \\
\hline F6 & 30 & 30 & $90.12 \pm 0.2$ & $24 \pm 1.4$ & $36 \pm 1.59$ & $88 \pm 2.98$ \\
\hline F7 & 40 & 30 & $92.23 \pm 0.35$ & $23 \pm 1.32$ & $43 \pm 2.01$ & $94 \pm 3.09$ \\
\hline F8 & 30 & 20 & $93.23 \pm 2.13$ & $22 \pm 1.21$ & $45 \pm 2.06$ & $98 \pm 3.34$ \\
\hline F9 & 20 & 20 & $95.45 \pm 2.36$ & $21 \pm 1.02$ & $48 \pm 2.46$ & $102 \pm 4.09$ \\
\hline F10 & 10 & 30 & $96.85 \pm 2.76$ & $20 \pm 0.08$ & $49 \pm 3.01$ & $104 \pm 4.89$ \\
\hline
\end{tabular}

${ }^{\star}$ All data expressed as mean \pm S.D.; $n=3 ; P \leq 0.05$.

\subsection{Stability studies}

The capability of dosage form to continue with its physical, chemical, therapeutic and toxicological specifications is known as stability. For evaluation of dosage forms, stability is an important tool which provides information regarding acceptance or rejection of these dosage forms [32-33].

\section{RESULTS AND DISCUSSION}

\section{Response surface methodology}

\section{Fourier Transform Infrared (FTIR) spectroscopy}

The pure drug CPM and solid admixture of drug and various excipients with formulation were characterized by FTIR spectroscopy for testing compatibility of CPM with its polymers and formulation. The IR transmission spectra of drug, polymers and formulation are given in Fig 1 . All the peaks were presented in their original position which shows that there is no drug-carrier interaction. The characteristic peak of CPM is $3250 \mathrm{~cm}^{-1}$ due to its amino group i.e. $\mathrm{N}-\mathrm{H}$

stretching. Other characteristic peaks present were $1580 \mathrm{~cm}^{-1}(\mathrm{C}=\mathrm{C}$ stretching), $1475 \mathrm{~cm}^{-1}$ (C=C stretching), $864 \mathrm{~cm}^{-1}$ (C-H stretching), $1352 \mathrm{~cm}^{-1}$ (C-C bending), $1697 \mathrm{~cm}^{-1}$ (-C=O stretching), $1576 \mathrm{~cm}^{-1}$ (C-N stretching), $702 \mathrm{~cm}^{-1}$ (C-Cl stretching). Similarly, the polymer used in formulation showed its characteristic peaks which are 
separate from drug which showed that drug was compatible with polymer and leads to good stability. The CCS showed its peaks such as $3430 \mathrm{~cm}^{-1}$ (-OH strecthing), $1740 \mathrm{~cm}^{-1}, 1611 \mathrm{~cm}^{-1}$ (C=O stretching).

\section{Scanning electron microscopy (SEM)}

The change in morphological appearance of drug was studied using scanning electron microscopy. The SEM micrographs showed that presence of excipients such as CCS, CPD and PEG 4000 influence the surface morphology of ODT's and pure drug. The surface morphology of ODT's demonstrated hard but rough and fragmented fibrous network like structures. Several regions on surface showed randomly scattered spherical particles of drug whereas excipients showed rough material structures.

\section{Differential scanning calorimetry (DSC)}

The DSC thermogram of pure drug CPM shows sharp endothermic peak at $139^{\circ} \mathrm{C}$ indicating its melting point. The glass transition of $\mathrm{CPM}$ was $41.04^{\circ} \mathrm{C}$. There is lack of drug peak in the thermogram of ODT showing that CPM was completely dissolved with the excipients and is present partially in crystalline and partially as molecular distribution. The thermograms of CCS and CPD indicated their melting points at $300^{\circ} \mathrm{C}$ and $83^{\circ} \mathrm{C}$ respectively and were according to their melting range. There was lack of glass transition temperature in thermogram of any excipients and also in ODT's.

\section{Thermogravimetric analysis (TGA)}

In this analysis, the drug CPM and formulated ODT's were subjected to controlled temperature program in a controlled atmosphere. In TGA graph of CPM showed that the mass remained constant with increasing temperature but when it approached to melting point of drug, the mass started to decrease. Similar phenomenon was also observed with the formulated ODT's. The thermogram of ODT showed three endotherms which are probably the melting points of $\mathrm{CPM}$ at $139^{\circ} \mathrm{C}, \mathrm{SSG}$ peak at $200^{\circ} \mathrm{C}, \mathrm{MCC}$ at $270^{\circ} \mathrm{C}$ which revealed that excipients or moisture content have no adverse effect on formulations.

\section{Disintegration time}

The disintegration data of the ODT's has shown in Table 3. The ODT's formulated with $10 \mathrm{mg}$ of SSG without addition of CCS and CPD showed extremely slow disintegration of 34 seconds. Whereas faster disintegration rate of 23 seconds was observed in ODT's (F7) containing CCS and CPD in a quantity of $40 \mathrm{mg}$ and $30 \mathrm{mg}$ but not to the level which is required in disintegration of ODT's. This behavior is due to presence of CCS which swells in the presence of water. Thus, quantity of CCS was decreased and CPD was increased in formulation F10 which contains CCS $10 \mathrm{mg}$ and CPD $30 \mathrm{mg}$ which was the best optimized formulation and showed faster disintegration of 20 seconds.

\section{In-vitro dissolution studies}

The in-vitro dissolution studies of the formulated ODT's were performed to evaluate the effect of CCS, CPD and SSG on release pattern of CPM. The dissolution rate of ODT's without CCS and CPD was extremely slow. Only about $19.8 \%$ drug was released in 1 minute and $64.67 \%$ drug was released in 5 minutes. But when CCS and CPD were incorporated then drug release reached $92.23 \%$ in 5 minutes which is not sufficient for a formulation like ODT's. This behavior may be attributed to swelling of CCS which forms a gel like mass entrapping some of the drug and prevents its release. When quantity of CPD is increased and CCS is decreased in F10, then $96.85 \%$ drug was released in 5 minutes. The above results indicate that ODT's containing $10 \mathrm{mg}$ CCS and 30 $\mathrm{mg}$ CPD are the most optimized formulation in respect of CPM release. Also effect of various polymers on dissolution behavior was evaluated. After evaluating, it was determined that CCS and CPD performed better than SSG.

\section{Response surface analysis}

The response surface models fit between the factors and measured responses is shown in the equations given below:

$\%_{\text {Disso }_{C P, C M}}=32.717-0.447 C P D-0.00383 C P D^{2}-0.153 C C S-$ $0.00783 C_{C S}^{2}+0.0215 C P D^{\star} C C S$

Dist. Time ${ }_{C P, C M}=68.13217+1.336 C P D-0.00389 C P D^{2}+0.11 C C S$ $+0.0158 C_{C S}^{2}-0.0351 C P D^{\star} C C S$

$W A R_{C P, C M}=26.3+1.87 C P D-0.018 C P D^{2}-1.02 C C S+0.038 C C S^{2}-$ $0.036 C P D^{\star} C C S$

$W T_{C P, C M}=56.87+8.73 C P D-0.2037 C P D^{2}-4.83 C C S+0.0703 C C S$ ${ }^{2}+0.0327 C P D^{*} C C S$

The response surface plots representing the relationship between the studied factors and measured responses is demonstrated in Fig 6A-6D.

The different batches of CPM ODT's were prepared by fusion method using superdisintegrants CCS and CPD and also in different polymer concentrations and all formulations were evaluated. [43-48]. Total of 10 formulations with different concentrations of excipients and fixed concentration of drug were evaluated. Weight variation of all formulations was observed in range of 253 to $291 \mathrm{mg}$ which was within acceptable limit for uncoated tablets as per USP. ODTs (batch F1 to F10) showed weight variation, thickness of $9.03 \mathrm{~mm}$ 
to $10.89 \mathrm{~mm}$, drug content of 92.0 to $99 \%$, water absorption ratio of 26 to $49 \%$, wetting time of 53 to $104 \mathrm{sec}$ and in-vitro drug release showed 64.67 to $96.85 \%$ within 5 minutes. The best optimized formulations (F9 and F10) showed best results from all formulations. In both, F10 is the most optimized formulation which showed disintegration time of 20 seconds. All the formulations were evaluated using different evaluation parameters. First evaluation parameter was weight variation which was performed with all 10 formulations. Weight variation was observed within the acceptable limits for ODT's as per USP. The primary requirement of ODT's is rapid disintegration. Angle of repose $(\theta)$ determines the internal friction and cohesion of particles. If value of angle of repose is higher, then it shows greater cohesiveness of powder but if its value is low, it shows non-cohesiveness of powder. All formulations showed good to acceptable flow properties as indicated by values of angle of repose (30.31-39.28). Carr's index showed values up to 20 which denote acceptable to good flow ability. All formulations had Hausner's ratio values within the stated limit. If the crushing strength (hardness) of ODT's is higher, it takes longer time to disintegrate. So the most important factor in formulation of ODT's is their mechanical integrity. The hardness of tablets was found to be in the range of 2.1 to $3.5 \mathrm{Kg} / \mathrm{cm}^{2}$ and friability was observed 0.44 to $0.69 \%$ which were also within acceptable limits. The disintegration time was observed between 20 to $34 \mathrm{sec}$. Disintegration test showed that formulations in which CCS and CPD were used showed rapid disintegration. But formulation in which CCS was added in quantity more than $10 \mathrm{mg}$ showed longer disintegration. This is due to rapid uptake of water from the medium. Due to swelling disintegration time decreases. Thus, the most optimized formulation containing $10 \mathrm{mg}$ CCS, $30 \mathrm{mg}$ CPD showed rapid disintegration. Thus, CCS was considered as optimum disintegrant. Percentage drug content and wetting time were also observed which were found to be within acceptable limits. It was found that in case of optimized formulation $32.12 \%$ drug was released in first 2 minutes. But in five minutes, about $96.85 \%$ of drug was released. Thus, superdisintegrants played the most important role in enhancing drug release. Thus formulation 10 was considered the best formulation. Now the FTIR spectra showed that there is no interaction between CPM and different excipients. Thus, it could be concluded that the superdisintegrants based ODT's of CPM showed fast disintegration, quick drug release and faster onset of action. The formulations containing CCS showed rapid disintegrating time of 20 seconds this is due to rapid uptake of water from the medium swelling and burst effect, there was the direct correlation between wetting time and disintegration time and there was no erosion on the tablet surface take placed during study of the wetting time. Thus. it was found that the formulation containing CCS showed rapid wetting time and disintegration time compared to other super disintegrants.

\section{Stability studies}

The stability studies were carried out according to ICH guidelines for one month for accelerated study at $40 \pm 2{ }^{\circ} \mathrm{C}$ and RH $75 \% \pm 5 \%$. The tablets were withdrawn after a period of 30 days and analyzed for physical characterization and drug content. Results are presented in Tables 4. The ODT's tablets were divided into three batches and kept at three different temperature at room temperature $25 \pm 2^{\circ} \mathrm{C} / 60 \pm 5 \% \mathrm{RH}$, at accelerated temperature $40 \pm 2{ }^{\circ} \mathrm{C} / 75 \pm 5 \% \mathrm{RH}$ and at cool temperature $4 \pm 2^{\circ} \mathrm{C} / 65 \pm 5 \% \mathrm{RH}$ as a function of time 30days and 60 days respectively. Then each sample was withdrawn at specific time (as mention in protocol) and then the drug release studies was performed. According to the observation it was observed that the sample stored at room temperature were shown a satisfactory drug release after a storage time of 30 and 60 days i.e. $80.91 \pm 0.81 \%$ and $80.30 \pm 1.63 \%$ respectively. While, the samples stored at accelerated and cool temperature, results in decrease in \% drug release. Hence, we can concluded that room temperature is suitable for the storage condition of Chlorpheniramine maleate ODT. All the analyses were carried out in triplicate and the results are reported as mean \pm SD.

Table 4. Stability study data of ODT

\begin{tabular}{|c|c|c|c|c|}
\hline S. no. & Month (days) & Stability conditions & Condition values & $\begin{array}{c}\text { Release in } \mathbf{5} \text { min }(\%) \\
\text { Formulation F10 }\end{array}$ \\
\hline \multirow{3}{*}{1.} & \multirow{3}{*}{30} & Room temperature & $\left(25 \pm 2^{\circ} \mathrm{C} / 60 \pm 5 \% \mathrm{RH}\right)$ & $80.91 \pm 0.81$ \\
\hline & & Accelerated temperature & $\left(40 \pm 2^{\circ} \mathrm{C} / 75 \pm 5 \% \mathrm{RH}\right)$ & $79.80 \pm 0.71$ \\
\hline & & Cool temperature & $\left(4 \pm 2^{\circ} \mathrm{C} / 65 \pm 5 \% \mathrm{RH}\right)$ & $76.17 \pm 0.12$ \\
\hline \multirow{3}{*}{2.} & \multirow{3}{*}{60} & Room temperature & $\left(25 \pm 2^{\circ} \mathrm{C} / 60 \pm 5 \% \mathrm{RH}\right)$ & $80.30 \pm 1.63$ \\
\hline & & Accelerated Temperature & $\left(40 \pm 2^{\circ} \mathrm{C} / 75 \pm 5 \% \mathrm{RH}\right)$ & $72.80 \pm 0.77$ \\
\hline & & Cool temperature & $\left(4 \pm 2^{\circ} \mathrm{C} / 65 \pm 5 \% \mathrm{RH}\right)$ & $74.90 \pm 0.70$ \\
\hline
\end{tabular}

${ }^{\star}$ All data expressed as mean \pm S.D.; $n=3 ; P \leq 0.05$. 


\section{Conclusion}

From the above work it was concluded that the release of drug from the F9 and F10 formulation was quick when compared to F1-F8. It showed that the combined effect of CCS and CPD gives synergistic effect. Thus, various superdisintegrants and application of the fusion method enhance dissolution, absorption, bioavailability, stability of ODT's and also manifold advantages of ODT's enhance patient compliance, decrease side effect of conventional dosage forms and increase its popularity in near future. It may be concluded that from the DSC, FTIR, drug content and in-vitro dissolution studies, ODT of F10 prepared by fusion method is the best formulation. As CPM is highly water soluble drug but it metabolizes in liver due to which its bioavailability decreases. But by formulating its ODT's, this problem can be eliminated. Thus a tablet with rapid dissolution and rapid absorption is formulated for rapid action within few minutes.

\section{Declaration of Interest}

The authors report no conflict of interest
Füzyon Yöntemiyle hazırlanan klorfeniramin maleat içeren ağızda dağılan tabletlerin formülasyonu ve değerlendirilmesi

\section{ÖZ}

Ticari ürün olarak klinik kullanıma sunulan birçok ilaç veriliş yolunma bağlı olarak terapötik değer kazanmaktadır. İnsanlar tablet ve kapsül gibi konvansiyonel dozaj formlarını, yolculuk gibi nedenlerle su bulamadıkları zamanlarda yutmakta zorlanmaktadırlar. $\mathrm{Bu}$ gibi durumlarda kullanılmak üzere ağız boşluğunda hızla dağılan tabletler dikkati çekmektedir. Ağızda dağılan tabletler, dil üzerine yerleștirildiğinde dozaj formu tükürük vasıtasıyla dağılmakta ve ilaç çözünmektedir. Katı formdaki ilaç hızla çözeltiye dönüşmekte ve bu durum ilacın emilimini ve etkinin başlamasını hızlandırmaktadır. Formülasyonlar hazırlandıktan sonra elde edilen tabletler; ortalama tablet ağırlığı ve ağırlık tekdüzeliği, sertlik, ufalanmaaşınma, dağılma zamanı, ilaç-polimer etkileşimleri, etken madde içeriği, su emme oranı, in-vitro ilaç salım özellikleri ve kısa süreli stabilite özellikleri açısından değerlendirilmiş, FTIR çalışmaları ve SEM çalışmaları yapılmıştır. F1-F10 olarak isimlendirilen tüm formülasyonların ortalama tablet ağırlığı ve ağırlık tekdüzeliği $253 \pm 0.05-291 \pm 0.61 \mathrm{mg}$, sertliği $2.1 \pm$ $0.1-3.5 \pm 0.07 \mathrm{Kg} / \mathrm{cm}^{2}$, ufalanma-aşınma yüzdesi \% $0.44 \pm 0.01$

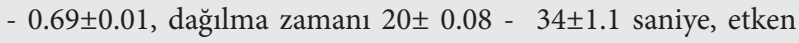

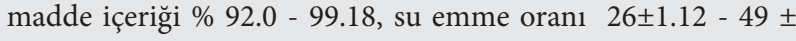
3.01, slanma zamanı $53 \pm 1.89$ - $104 \pm 4.89$ saniye ve 5 dakika içerisinde in-vitro ilaç salım yüzdesi \% 85.66 -99.88 olarak belirlenmiştir. FTIR çalışmaları, ilaç ve polimer arasında bir etkileşim olmadığını göstermiştir. Stabilite çalışmaları ilacın farklı sıcaklık ve nem ortamında saklandığında ilaç salım özelliğinin değişmediğini göstermiştir. Elde edilen sonuçlar füzyon yöntemiyle hazırlanan ve klorfeniramin maleat içeren ağızda dağılan tabletlerin hızlı dissolüsyona uğradığını göstermiştir.

Anahtar kelimeler: Klorfeniarmin maleat, füzyon yöntemi, FTIR, SEM, Tam Faktöriyel Tasarım

\section{References}

1. Douroumis DD, Gryczke A, Schminke S. Development and evaluation of cetirizine $\mathrm{HCl}$ taste-masked oral disintegrating tablets. AAPS PharmSciTech 2011; 12: 141-51.

2. Martino PD, Martelli S, Wehrlé P. Evaluation of different fast melting disintegrants by means of a central composite design. Drug Dev Ind Pharm 2005; 31: 109-21.

3. Haware RV, Chaudhari PD, Parakh SR, Bauer-Brandl A. Development of a melting tablet containing promethazine $\mathrm{HCl}$ against motion sickness. AAPS PharmSciTech 2008; 9: 1006-15.

4. Modi A, Tayade P. Enhancement of dissolution profile by solid dispersion (kneading) technique. AAPS PharmSciTech 2006; $7: 68$.

5. Gupta V, Gupta M, Madan AK. Development of modified dosage form for enhancement of dissolution rate through amalgamation of solid dispersion and cube sugar or sintering technology using famotidine as a model drug. J Pharm Sci Technol 2009; 63:58-70.
6. Ahmed IS, Nafadi MM, Fatahalla FA. Formulation of a fastdissolving ketoprofen tablet using freeze-drying in blisters technique. Drug Dev Ind Pharm 2006; 32: 437-42.

7. Sarfraz RM, Khan HU, Mahmood A, Ahmad M, Maheen S, Sher M. Formulation and evaluation of mouth disintegrating tablets of atenolol and atorvastatin. Indian J Pharm Sci 2015; 77: 83-90.

8. Seager H. Drug delivery Products and the Zydis fast dissolving dosage forms. J Pharm Pharmacol 1998; 58: 375-82.

9. Mizumoto T, Masuda Y, Kajiyama A, Yanagisawa M, Nyshadham JR. Tablets quickly disintegrating in the oral cavity and process for producing the same. US Patent 6,589,554; 2003.

10. Shah PP, Mashru RC. Development and evaluation of artemether taste masked rapid disintegrating tablets with improved dissolution using solid dispersion technique. AAPS PharmSciTech 2008; 9: 494-500.

11. Fu Y, Yang S, Jeong SH, Kimura S, Park K. Orally fast disintegrating tablets: developments, technologies, tastemasking and clinical studies. Crit Rev Ther Drug Carrier Syst 
2004; 21: 433-75.

12. Yunxia B, Sunada H, Yonezawa Y, Danzok K. Evaluation of rapid disintegration tablets prepared by direct compression method. Drug Dev Ind Pharm 1999; 25: 571-81.

13. Gopal VS, Averineni RK, Yogendra NU, Karktik A, Ranjan OP, Ginjupalli K, Pandey S, Udupa N. Enhanced dissolution and bioavailability of Gliclazide using solid dispersion techniques. Int J Drug Dev 2010; 2: 49-57.

14. Danjo K, Kozaki K, Sunada H, Otsuka A. Influence of the molecular weight of binding agents on the physical properties of granules and tablets. Chem Pharm Bull 1994; 42: 2121-5.

15. Bala R, Sharma S, Sharma N, Gupta DG. Development of nonbitter zolpidem tartrate mouth dissolving tablet. J Pharm Res 2009; 2: 1530-5.

16. Gandhi CK, Patel MR, Patel KR, Patel NM. A review: Taste masking in pharmaceuticals. Int J Pharm Res Dev 2011; 3: 19 $-26$.

17. Lakshmi CSR, Sagar PA, Anup VT, Chaudhary JJ, Nitesh JP, Vedhavati SV. Development and characterization of melt in mouth tablets of atenolol by sublimation technique. Int J Pharm Res Dev 2011; 3: 27-36.

18. Pahwa R, Piplani M, Garg VK, Rao R, Lamba HS. Formulation and evaluation of orally disintegrating tablets: comparison of natural and synthetic superdisintegrants. Der Pharm Lett 2011; 3: 407-18.

19. Rajitha K, Shravan YK, Adukondalu D, Ramesh G, Rao YM. Formulation and evaluation of orally disintegrating tablets of buspirone. Int J Pharm Sci Nanotech 2009; 1: 327-34.

20. Raju SA, Rampure MV, Shrisand SB, Swamy PV, Nagendra DK, Baswaraj B, Raghunandan D. Formulation and evaluation of orodispersible tablets of alfuzosin. Int J Pharm Tech Res 2010; 2: 84-8.

21. Yuan CS, Karrison T, Wu JA, Lowell TK, Lynch JP, Foss JF. Dose-related effects of oral acetaminophen on cold-induced pain: a double-blind, randomized, placebo-controlled trial. Clin Pharmacol Ther 1998; 63: 379-83.

22. Kalia A, Khurana S, Bedi N. Formulation and evaluation of mouth dissolving tablets of oxcarbazepine. Int J Pharm Sci 2009; 1: 12-23.

23. Devi NK, Rani AP, Mrudula BS. Formulation and evaluation of oral disintegrating tablets of montelukast sodium, effect of functionality of superdisintegrants. J Pharma Res 2010; 3: 8038.

24. Mukesh P, Ratnaparkhi, Mohanta GP, Upadhyay L. Review on: Fast dissolving tablet. J Pharm Res 2009; 2: 5-12.

25. Kaith BS, Sharma R, Kalia S, Bhatti MS. Response surface methodology and optimized synthesis of guar gum-based hydrogels with enhanced swelling capacity. RSC Adv 2014; 4: 40339-40344.

26. Steinberg DM, Kenett RS. Response surface methodology. Wiley StatsRef: Statistics Reference Online. 2014; doi: 10.1002/9781118445112.stat04105.

27. Kharb V, Saharan VA, Dev K, Jadhav H, Purohit S. Formulation, evaluation and 3(2) full factorial design-based optimization of ondansetron hydrochloride incorporated taste masked microsphere. Pharm Dev Tech 2014; 19: 839-52.

28. Dave BS, Amin AF, Patel MM. Gastroretentive drug delivery system of ranitidine hydrochloride: formulation and in vitro evaluation. AAPS Pharm Sci Tech 2014; 5:1-6.

29. Trapani A, Laquintana V, Denora N, Lopedota A, Cutrignelli A, Franco M, Trapani G, Liso G. Eudragit RS 100 microparticles containing 2-hydroxypropyl-beta-cyclodextrin and glutathione: physicochemical characterization, drug release and transport studies. Eur J Pharm Sci 2007; 30: 64-74.

30. Upendra K, Raghavendra NG. Design and development of aceclofenac fast dissolving tablets by amorphous solid dispersion technique using modified aegle marmelos gum. Int J Pharm Res Dev 2011; 3: 201-10.

31. Philippe C. Coated granules based on angiotensin-converting enzyme inhibitor. US Patent 20040171669; 2001.

32. Kornblum SS, Stoopak SB. A new tablet disintegrating agent: cross-linked polyvinylpyrrolidone. J Pharm Sci 1973; 62: 43-9

33. Shah U, Augsburge L. Evaluation of the functional equivalence of crospovidone NF from different sources. II. Standard performance test. Pharm Dev Technol 2001; 6: 419-30.

34. Bi Y, Sunada H, Yonezawa Y. Preparation and evaluation of a compressed tablet rapidly disintegrating in the oral cavity. Chem Pharm Bull 1996; 44: 212-17.

35. Nogami H, Nagai T, Fukuoka E, Sonobe T. Disintegration of the aspirin tablets containing potato starch and microcrystalline cellulose in various concentrations. Chem Pharm Bull 1969;17:1450-5.

36. Franse'n N, Morin M, Bjロrk E, Edsman K. Physicochemical interactions between drugs and superdisintegrants. J Pharm Pharmacol 2008; 60: 1583-9.

37. Soh JL, Grachet M, Whitlock M, Lukas T. Characterization, optimisation and process robustness of a co-processed mannitol for the development of orally disintegrating tablets. Pharm Dev Technol 2013; 18: 172-85.

38. Thompson JA, Shioshita GW. Influence of substrate configuration on chlorpheniramine $\mathrm{N}$-demethylation by hepatic microsomes from rats, rabbits, and mice. Drug Metab Dispos 1981; 9: 5-9.

39. Babar A, Ray SD, Patel NK, Plakogiannis FM, Gogineni P. In vitro release and diffusion studies of promethazine hydrochloride from polymeric dermatological bases using cellulose membrane and hairless mouse skin. Drug Dev Ind Pharm 1999; 25: 235-40.

40. Velissaratou AS, Papaioannou G. In vitro release of chlorpheniramine maleate from oinment bases. Int J Pharm 1989; 52: 83-6.

41. Babar A, Bhandari RD, Plakogiannis PM. In vitro release studies of chlorpheniramine maleate from topical bases using cellulose membrane and hairless mouse skin. Drug Dev Ind Pharm 1991; 17: 1027-40.

42. Nagar P, Singh K, Chauhan I, Verma M, Yasir AK, Sharma R, Gupta N. Orally disintegrating tablets: formulation, preparation techniques and evaluation. J Appl Pharm Sci 2011; 01: 35-45.

43. Sharma D, Kumar D, Singh M, Singh G, Rathore MS. Fast Disintegrating Tablets: A new era in novel drug delivery system and new market opportunities. J Drug Del Ther 2012; 2: 74-86.

44. Hirani JJ, Rathod DA, Vadalia KR. Orally disintegrating tablets: a review. Trop J Pharm Res 2009; 8: 161-72.

45. Abay FB, Ugurlu T. Orally disintegrating tablets: a short 
review. J Pharm Drug Dev 2015; 3: 1-8.

46. Arora P, Sethi VA. Orodispersible tablets: a comprehensive review. Int J Res Dev Pharm Sci 2013; 2: 270-84.

47. Hao L, Min L, Wen Q, Zheyi H, Ed B, James J, Hassan A. Evaluation of chlorpheniramine maleate microparticles in orally disintegrating film and orally disintegrating tablet for pediatrics. Drug Dev Ind Pharm 2014; 40: 910-8.

48. Giri TK, Tripathi DK, Majumdar R. Formulation aspects in the development of orodispersible tablets: An Overview. IJPPS 2010; 2: 38-42. 